\title{
Opposition in the New States of Asia and Africa
}

\section{Edward Shils}

\section{The situation of opposition parties in the new states}

The new states of Asia and Africa present a variegated picture with respect to the status and mode of action of their opposition parties. In only about a third of the new states are opposition parties regarded as constitutionally legitimate. Israel, Lebanon, Morocco, India, Ceylon, Sierra Leone, Senegal, Nigeria, Malaysia, Philippines, Sudan, and a few others allow opposition to exist in a public and institutional form. In Israel a system of a frequently varying coalition government and open opposition parties prevails, with full freedom of public discussion. In Nigeria, the multi-party system with a coalition government and open opposition parties still functions, although it nearly collapsed earlier this year because a major, but minority, party in the previous coalition boycotted the federal election - as part of its leader's unsuccessful scheme to make a coup d'état. In India, which has had the most stable and completely civilian government, opposition is free; parties in opposition to the ruling party are numerous and ineffectual, and for the most part work within the constitution. Ceylon permits two major parties and a considerable number of lesser parties. Both these South Asian regimes permit full freedom of discussion, although the previously incumbent Ceylonese party had sought to control the press. Pakistan and Sudan, having witnessed the dissolution of parties by military regimes, have now returned to something like party systems. Malaysia, too, maintains one, although it has very recently had to amputate one part of the country to avoid suppression of the locally-based Peoples' Action Party of Singapore. Sierra Leone also maintains a party system which has proceeded without crisis since independence. The Arab Middle Eastern states, the Maghreb states except Morocco, nearly all of the French-speaking African states, Ghana, Tanzania, Uganda, Kenya, Malawi, and Burma, do not have public opposition parties.

None of these new states is immune from oppositional activity. In 


\section{GOVERNMENT AND OPPOSITION}

about half of them, the incumbent governments in the past eight years have had to admit the factual existence of opposition by means of conspiracy, assassination or a successful coup d'etat. Most of the acts of repression of an illegal opposition allegedly intending to employ violent means have been committed within states already denying both the constitutional legitimacy of opposition and indeed even the existence of any oppositional interests except 'reactionary' ones. Opposition has occurred in these states after it has already been legally abolished and its existence implicitly denied.

Among the one-party states, Guinée acknowledged recently that its youth might be tempted to become oppositional. It had already condemned the leaders of its teachers' union for illegal opposition which it designated as subversion. The most stable of the one-party regimes, Tunisia, has seen one of its major architects in exile and assassinated under obscure circumstances. It has itself contended that it was the object of conspiracy. In Algeria, there has been a coup d'état by the military in a harshly repressive one-party state which had already experienced during its brief existence a regional-military rebellion, and the trials of conspirators against the previously ruling government. In the new one-party regime in Tanzania, no opposition is admitted to exist, but the leader of the opposition, $\mathrm{Mr}$ Tumbo, is banished from public life. The newly joined members of the government from Zanzibar have encouraged or permitted the resistance of their followers to the desires of the government in Dar-es-Salaam. In Ghana, the government has on several occasions made accusations of subversive intentions, alleged plots to assinate the President and noted other manifestations of opposition to the rulers of the country. In Togo, President Olympio was assassinated by a group of army officers and non-commissioned officers and politicians recalled from exile to join in the conspiracy. Similar manifestations have occurred in many of the other one-party regimes.

Still, what is notable about the new states is not that opposition exists. That is to be expected. Nor is it surprising that they have not been as successful as the totalitarian states, ${ }^{1}$ which some of them admire as embodiments of modernity, in suppressing the emergence from time to time of oppositional interests and sentiments. Their elites have had unwittingly to acknowledge this publicly, on the occasion of their displacement by the forcible action of a previously closed

1 Not that any totalitarian states have been able for long to avoid manifestations of opposition.

I 76 


\section{OPPOSITION IN ASIA AND AFRICA}

opposition. ${ }^{2}$ What is more interesting at this point in our discussion is that in so many states in which the rulers strive for modernity, for progressive and differentiated societies, they should be so intolerant of opposition, and particularly of open opposition in the form of constitutional parties, contending and criticizing in public.

\section{The attitude of dominant parties towards opposition}

We must, therefore, seek to answer the question: Under what conditions does the ruling party tolerate the opposition? Or in an alternative formulation: Under what conditions does the ruling party either abolish the legal existence of opposition parties or force them to amalgamate with the ruling party?

As a first approximation, we may say that toleration of opposition exists where one or several of the following factors are present: (i) the ruling party alone or in coalition is obviously safe by a very substantial majority and is confident of its continued safety; (ii) the ruling party has a strong attachment to constitutional government; (iii) the conduct of the opposition is relatively unaggressive; (iv) the opposition is large and difficult to suppress without the probability of strong resistance by arms or by significant public opinion; and ( $v$ ) the rulers do not regard themselves as the sole bearers of the charisma of nationality.

The ruling party suppresses opposition parties or forces them to coalesce with itself when it feels insecure about the stability of its majority and where the opposition, although weak, is regarded as a danger to the security of the incumbent elite. The assessment of danger to the security of the state is a subjective phenomenon. It is often unconnected with any realistically assessed high probability of a successful effort of the opposition party to displace the ruling party.

Efforts to suppress the public existence of an opposition party have hitherto been successful except where the opposition has a particular territorial or regional base ${ }^{3}$ or where it has substantial foreign support (e.g., the difficulties of the central governments in CongoLeopoldville, Sudan, Iraq, India, and Indonesia in suppressing the territorially based opposition in Katanga and Orient Provinces, in the

\footnotetext{
2 Where subversive powers are strong - the army is almost always the only strong subversive power - it is easy for them to overthrow the incumbent party. The institutions of public order in most of the new states are very feeble and cannot successfully cope with strong subversive elements.

3 The survival of the multi-party system in Nigeria is very much a function of the distinctive territorial bases of the various partics.
} 


\section{GOVERNMENT AND OPPOSITION}

Southern Sudan, in Kurdistan, Nagaland and Sumatra and the Celebes). The condemned opposition parties have not as parties been able to resist effectively - their leaders have been gaoled or driven out of the country and their party machines have crumbled. They have not been able to call strikes or rally counterpressure when the governing party has wished to take strong action against them.

Despite the almost always evident incapacity of open opposition parties to resist their own destruction - which would lead to the conclusion that they could not by the same token subvert or overcome the incumbent government (even if they wished) - ruling parties in the new states nonetheless incline very often to the suppression of those who oppose them. Indeed if the allegedly subversive opposition parties were strong enough to resist their dissolution, the ruling parties would perhaps be less ready to suppress them. ${ }^{4}$

It seems clear that it is not because the governments have been in real danger from the opposition parties that they have suppressed them. When it suppresses or amalgamates an opposition party the government does not often allege that it is doing so because the opposition actually endangered its position. What it reacts against is an imputed subversive intention - a subversive state of mind - rather than a factual probability of subversion. Prohibition or suppression is a punishment for a wrong state of mind rather than a forestalling of a probable pernicious action.

The argument usually given for the suppression of opposition is that there is no need for an opposition because the ruling party and the people are one. It is also said that because of a shortage of personnel for the exacting tasks of development, it is wasteful for educated persons to be encouraged to spend their time in criticizing when they should be working for the progress of their countries. Another argument is that the criticisms of opposition parties would distract the populace from its concentration on the tasks set by the development programmes. Finally, it is said that the abolition of opposition parties enhances the stability of government and thereby provides the firm framework needed for social and economic development.

There is not much empirical basis for these arguments. In no country in the world are party and people one, neither in the underdeveloped countries nor in the advanced ones. It is no more than a

4 Conversely, if the opposition parties were as dangerous as their ruling antagonists assert, they probably could succeed in their subversion because the ruling parties and their governments are also very fragile. Their powers of resistance are not very great, judging by the number of successful coups undertaken by oppositional elements. 


\section{OPPOSITION IN ASIA AND AFRICA}

doctrinaire belief of political elites that they embody completely all the interests of the people whom they rule and that they care for them all equally and completely. But the fact that it is only a belief does not make it less real or less effective. In many cases it probably is a sincerely held belief.

It is certainly true that the new states must economize in the use of scarce educated talent. Very few of the new states have reached the point where they have an unemployable surplus of university graduates and technically trained 'cadres'. (India is the most outstanding exception.) But the suppression of opposition does not result in the employment of the talents of the opposition. They are very often, as in Ghana, incarcerated or exiled. Even if left at liberty they are seldom given important posts in the government-although in Kenya at least some of the leaders of the Kenya Democratic Union were thus employed when it was amalgamated with the Kenya African National Union. Still, the belief that talents must be conserved and used for the fulfillment of an over-ridingly important goal is a reality, too.

There are no grounds for believing that the inefficacy of so many measures for the improvement of agricultural technique and output, and for the promotion of industrial production in the countries which have permitted open opposition, are attributable to the demoralizing effect of the public criticism of government measures by open opposition parties or a free press. The economic misfortunes of Guinée certainly cannot be assigned to such a cause, because there is no public opposition in Guinee. People do not work harder or more efficiently when they are not allowed to know of criticisms of government policies. States without open opposition do not have higher rates of economic growth than do states which tolerate opposition. Where, as in the case of the Ivory Coast, the economic growth rate of a oneparty state is relatively high, it is largely a consequence of foreign aid.

As regards the argument from stability, this, too, has no empirical foundation. The one-party governments - governments which have suppressed their oppositions - are not less unstable than the types of regime they do not wish to resemble. Attempts at coups d'état have happened more frequently in one-party regimes than in regimes with open opposition parties (e.g. Mali, Ivory Coast, Togoland, Dahomey, Syria, Iraq).

Since the arguments which are used to justify the suppression of opposition by governing parties seem to be empirically baseless, why are they employed ? They are employed in part to give a justification, in terms of a principle involving the common good, to actions which 


\section{GOVERNMENT AND OPPOSITION}

serve the particular advantage of the ruling party. They are invoked because the ruling party is attached to the symbols and roles of power and does not want to be displaced. They are also invoked and applied because they are actually believed.

Why are they believed? The beliefs in question appear to derive from an unarticulated political metaphysic, 5 from a conception of the nation as a metaphysical essence which finds its purest manifestation in those who believe in and give expression to it by the fact of their incumbency in the positions of authoritative responsibility for the custody and propagation of that unitary national essence. 6 The metaphysic of the 'national essence' grew into a mind-filling reality in the course of the agitation and negotiations for independence. Those who agitated for the independence of the still scarcely existent nation became possessed by this essence, which they sought to emancipate from the accidents which encumbered it, such as the rule of the ethnically alien, the influence of traditional indigenous authorities, and others who manifested in their political action or in their tribal and communal attachments their non-participation in that essence.

According to this 'metaphysic of the nation,' one cannot simultaneously be of the nation and yet antagonistic towards its highest and fullest embodiment. Where society is very different from the state, the occupants of the ruling positions in the state regard themselves as the exclusive custodians of what is essential in the society. The empirically existing society, with its tribal divisions, its traditional leaders, its educated class with divergent loyalties and aspirations, is a bad accident of history, of mistakes by dead and living persons who did not or do not see that their existence is fundamentally anomalous. That is the way in which the rulers conceive of themselves and their competitors.

How could such a conception have arisen? It has two major external intellectual sources: Rousseau and the doctrine of the dictatorship of the proletariat, to both of which many French-speaking African politicians were susceptible in the latter part of the 1940's and more so in the 1950's. Of the four English-speaking African states which have suppressed or amalgamated with their publicly organized opposition, at least one has been markedly influenced by the Leninist

5 Professor Arthur Lewis in his forthcoming work, Politics in West Africa, writes: 'A struggle for independence is highly emotional ... The men who thrust themselves forward ... feel that they are Heaven-sent, and that anyone who stands in their way is a traitor to Heaven's cause.'

6 This metaphysic, although of a quite different historical origin, bears a close structural similarity to the historical metaphysics of Marxism-Leninism, which places the Communist Party in an analogous position in the communist countries. 


\section{OPPOSITION IN ASIA AND AFRICA}

idea of the dictatorship of the proletariat, and the others have been somewhat influenced by it. But the doctrinal influences do not explain why the opposition has been suppressed in so many countries which have not been influenced at all by Rousseau and very little by Marxism-Leninism. The dominant political elites have their prejudices and some of them come from and are reinforced by political theories. But by and large, political theory seems a factor of minor significance - almost an epiphenomenon - entering into a pattern of thought which is generated from experience, from passion and the necessities of collective pride, individual dignity and vanity, and from the colonial situation.

There is an inherent dynamic in the colonial situation of proud persons with a need for dignity and a resentment against those who deny it to them. There is a need for self-identification, which enhances dignity. The nature of this self-identification is influenced by the scope of the rejected but still obtaining colonial authority, and the ineffable experience of a distinguishing colour. It gains intensity from the self-identification which arises first from an active leading role in the independence movement and then from the fact of incumbency in the central positions of authority in the new states. The very thinness of its spread in the rest of society makes for a more acute consciousness of one's own circle of confrères as the exclusive bearers of the quality of nationality.

We must not, however, overlook the simple facts of attachment to power and the prestige and perquisites associated with power, of irritation at simply being made the focus of criticism, and of touchiness in response to criticism for shortcomings of which one is more or less aware. There is also the further unpleasantness of being criticized by persons who were once one's colleagues, indeed almost brothers. This wounded and aggressive response to criticism, actual and anticipated, draws additional force from the antagonism felt towards critics from ethnic groups other than that of the leaders of the dominant party, an antagonism and rivalry which are prior to the relationship of ruler and critical opponent. ${ }^{7}$

${ }^{7}$ Ethnic antagonisms within the broader circles of the elites and counter-elites of the new states are aggravated by the strain of the ethnic attachments within the self of those who seek to transcend them in a higher national identity.

It must, however, be pointed out that in spite of the anxieties of the elites of the ruling parties about the dangers of disintegration because of divergent ethnic attachments, the suppression of open opposition parties in order to avoid such disintegration has not been justified in the result. The problem of national unity is an urgent one, but the suppression of parties has not prevented the South Sudanese from revolting. On the other hand, no state already established and functioning has broken up because of secessionist tendencies among its ethnic minorities. 


\section{GOVERNMENT AND OPPOSITION}

The sense of exclusive custodianship of the national essence which results in the identification of state, party and society is not equally pronounced everywhere. There are countries where it has become attenuated by experience and the passing of time and where it has to face a deeper tradition of constitutional government. In these countries, although ruling politicians become irritated with their critics, they do not proceed repressively against them because they acknowledge their fundamental right to existence. India is the chief example of a new state where a longer process of growth of the sense of nationality and a longer experience of political activity, as constitutional as was possible under a colonial regime, ${ }^{8}$ gradually established a powerfully compelling tradition of respect for the institutions and procedures through which collective decisions are made. Ceylon shows similar features. Pakistan, despite its failures and the military interregnum and despite the rather short history of the sentiment of Pakistani nationality and the grave ecological obstacles to its formation, likewise seems to have benefited to some extent from this prolonged exposure to the culture of constitutionalism.

Sierra Leone and Israel are also the bearers of a well established constitutional culture, and of a longer history of the sense of nationality that is to be found in most of Africa. In Israel, it has been imported with the political culture of the dominant parties. In Sierra Leone, it is part of a relatively well established general culture and also owes much to the exceptional personal qualities of the brothers Margai. In these more tolerant regimes, the image of the nation and the sense of national identity have become sufficiently flexible to coexist with perceived differences which are not held to diminish the reality of the nation. Nationality there does not require uniformity.

Elsewhere in the third world, where opposition parties are permitted to exist as long as they maintain a discreet and modest attitude - as in Morocco and in Senegal - or where they are so strong that to attempt to suppress them would precipitate a crisis more serious than the rulers care to face - as in Nigeria and Lebanon - and in Malaysia until a short time ago - political prudence on the part of sober and artful political leaders seems to be a major factor. Of course, in all these cases there is a mixture of motives.

\footnotetext{
8 Colonial regimes were not congenial to the growth of a discipline of constitutional or civil politics. In most of the new states a number of parties came into existence only a short time before the granting of independence, when nationalistic enthusiasm was extremely intense.
}

I 82 


\section{OPPOSITION IN ASIA AND AFRICA}

\section{The mode of action of opposition parties}

The necessity of contending with an incumbent elite which is so fundamentally distrustful of opposition - and above all of public opposition - renders the situation of opposition parties difficult. 'Dining with the opposition' - in the phrase attributed to Sir William Harcourt - is a necessary condition for bringing the opposition into the consensual relationship with rulers which is the foundation of constitutional opposition parties. Where the incumbent elite, which, in most cases, has the upper hand, believes that those who oppose them in particular matters are their enemies in all that counts in life, a corresponding attitude is bred in the opposition. If enmity is cultivated, enmity is harvested.

The traditional pomp and elaborate procedural machinery of parliamentary institutions which in advanced countries restrains the impulses of opposition parties has not brought about the same consequences in the new states. The formalities have not corresponded to or evoked deeply rooted attitudes. Parliamentary experience has had too short a life and too recent a birth. India, where experience of parliamentary debate is older, is an exception. The speaker's position there is more generally esteemed and the strong machinery of party discipline by the ruling party leadership has established an air of decorum which wild opposition cannot unsettle, and which imposes a tone of sobriety on the opposition parties. But in India, too, "walkouts' are not infrequent, even among oppositional parliamentarians who think they are committed to the parliamentary system.

In most of the other new states, when opposition parties were allowed to exist, they opposed with relatively little regard for parliamentary procedure and even less regard for parliamentary etiquette. African political language is very rough - those who use it may not mean it as aggressively as it must sound to those who listen to it. It is filled with threats and accusations which may or may not be seriously intended but which heighten the tension of parliamentary life. The government speaks in such terms and opposition parties reply in kind. As a result, the opposition party appears to be more inimical to the incumbent government and to public order than in fact it is.

Nor does the structure of the party system as it operates in the new states do much to bring the opposition into the partially consensual relationship necessary for the effectiveness of an open opposition party. In none of the new states of Asia and Africa has the opposition party enjoyed the beneficial influence of a two-party system, which disciplines opposition by holding before it the possibility of assuming 


\section{GOVERNMENT AND OPPOSITION}

office and then bearing the responsibility for doing a better job than those it has been criticizing. In some of them when independence was achieved, one major party, considerably outweighing all the other parties, at first either maintained or extended its preponderance. India, Burma, Pakistan, Ghana, Tanganyika and Tunisia were instances of this. It is both discouraging to opposition and injurious to its action when one heavily dominant party appears to be immoveable. People do not like to back a certain loser and the opposition parties are therefore bound to be small and to become discouraged and desperate under these conditions. Discouragement about their prospects of growth not only keeps them small, it also makes them smaller by stirring up the jealousies and disputes which are endemic in failing organizations. Despair drives the opposition into wild accusations, 'walk-outs', boycotts of parliamentary sessions, obstructive actions, nonsensical charges, triviality, etc. Such behaviour dooms the opposition party to ineffectiveness. The aggressiveness of oppositional rhetoric, which is promoted by these conditions, also lays them open to charges of subversive intent, with which the dominant party is in any case ready enough.

Some of the new states came into existence with a number of approximately equal competing parties - as in Indonesia, Israel and Nigeria - and a coalition was necessary for the establishment of government. No more than government by congress-like parties do coalition governments, unless they are conducted with tact and loyalty, generate the parliamentary culture necessary to 'civilize' the conduct of opposition parties, both outside and within the coalition government. On the contrary, the weaker parties in a coalition, having to compromise their principles so much before the demands of the major party, fear that their followers will suspect their probity. They must, therefore, give some evidence to their following and to those whose support they might seek in the future that their principles have not been wholly compromised. Thus they oppose within the government and outside as well. Much of their opposition is symbolic, because when they are moderately responsible or fairly attached to a share in office, they do not wish to break up the coalition. Hence they are oppositional in rhetoric, as if to hide their attachment to office. This has the effect of stimulating the opposition outside the government, since the outsiders must, to maintain their oppositional self-respect, oppose even more vehemently.

These features of minor parties within coalition governments appear also in cases in which the dominant congress-like party of the 


\section{OPPOSITION IN ASIA AND AFRICA}

moment of independence - as in Burma or Pakistan - begins to falter and disintegrate as a result of the wear and tear of office and of the demoralizing effects of long unchallenged supremacy. Factions within the party become more pronounced; they become almost embryonic parties. In public speeches and at party conventions, opposition to the internally dominant group becomes embittered and aggressive. It becomes difficult to patch up these conflicts to give a convincing picture of a unified party to the public. Although this situation is sometimes welcomed by political analysts who think that it foretells the formation of a fruitful dominant party-opposition party pattern, it does not ordinarily work that way. It increases acrimony simultaneously with appeals to party unity. The ruling party becomes more inefficient and indecisive but it continues in power because the opposition parties are so feeble.

The prospect of disintegration encourages the opposition parties outside the government, but it does not 'civilize' them. It only excites them. The small and ineffective oppositional parties of the time are not made stronger or more reasonable by the imminence of the breakup of the congress-like ruling party. They know that they will not be called upon to govern. The best they can hope to attain is portfolios in a coalition in which, while enjoying the fruits of office, they too can maintain their integrity by oppositional rhetoric. Thus the prospect of disintegration of a once unchallenged monolithic party increases the agitation of a clamorously negative opposition party. Disintegration has an unsettling effect, as occurred with the disintegration of the Muslim League in Pakistan and seems to be going on in India now.

An insecurely placed dominant party sometimes takes to itself as partners in a coalition one or more lesser opposition parties to enable it to keep its ascendancy over its major rival. Sharing in government does not domesticate such oppositional parties. The persisting strength of their oppositional dispositions coupled with their awareness that they have a good bargaining position rigidifies their outlook. They must not discredit themselves before their followers, and they have an opportunity to strike a blow for their ideals; the result is a combination of the conduct of minor coalition partners and of minor opposition parties in the presence of a progressively weakening dominant or congress-like party. A 'culture of coalition' which is so much needed in the new states is prevented from developing under these conditions. 


\section{GOVERNMENT AND OPPOSITION}

\section{The strength of opposition parties}

For all their fiery rhetoric, open opposition parties in the new states are seldom dangerous to the ruling parties either in open electoral campaigns or in parliamentary voting or in conspiratorial activities. They are usually too weak to be dangerous. Conspiratorial and subversive activity is most commonly reported from the one-party states which do not permit opposition parties. In Senegal, it was not the existing or once public opposition parties which conspired to assassinate the president or to seize power. In Ghana, the last alleged plot to assassinate the president came from within his own monolithic party. It was not an open opposition party which assassinated Prime Minister Solomon Bandaranaike or President Sylvanus Olympio. It was not a public (or even a clandestine) opposition political party which instigated the mutinies in the three East African states. The rebellion in Sumatra in 1958 was not the work of an open opposition party, although party politicians were associated with it. It was only in Zanzibar that an open opposition political party undertook to overthrow the incumbent government by conspiratorial, revolutionary means.

Nor, for that matter, have military coups d'etat been carried out in collaboration with open opposition parties - neither in Pakistan, nor in the Sudan, nor in Burma have the open opposition parties worked with the military in their preparations to take power to themselves. Rather, in two of the three cases, it was civilian politicians of the ruling party who drew the military into politics. In Nigeria it was one of the partners in the ruling coalition, the NCNC, which tried to involve the army in a seizure of power in January 1965. Thus, although ruling parties sometimes allege that the opposition parties must be proceeded against because otherwise they would be strong enough and malevolent enough to damage the political order, this is not the case.

The causes of their weakness are various. One of them is poverty. There are few rich indigenous businessmen ${ }^{9}$ willing to support opposition parties. The class as a whole is not numerous, and even when they are rich enough, they are also usually prudent enough not to endanger their fortunes by intensifying the antagonism of the ruling party - already sufficiently hostile to private capitalist enterprise not to need the additional incentive for confiscation which in-

\footnotetext{
9 In those countries which have not yet driven out foreign businessmen, the latter are extremely cautious in avoiding any activities which might jeopardize their relations with the ruling party. They do not contribute to the treasuries of opposition parties.
} 


\section{OPPOSITION IN ASIA AND AFRICA}

volvement in opposition would provide. Moreover, with such farreaching government control of the economy, private businessmen have a positive reason for supporting the ruling party - otherwise, how could they get the licences, the foreign exchange, etc., which they need to carry on their businesses under circumstances which are intended to create difficulties for them ?

How can a political party live in a new state ? How can it keep its members from becoming disgruntled and giving their support to its opponents? It must live in part from the government treasury. Its cadres must have employment, and employment is mainly government employment. A certain amount of use of government money diverted for the immediate use of the party is sometimes necessary for the ruling party to keep itself coherent through the maintenance of the loyalty of its followers. Opposition parties have no access to public money. And lacking private funds they cannot support party functionaries, or pay for electoral campaigns on a country-wide scale, such as would be necessary to turn them into real competitors of the ruling party. Since they cannot build up a country-wide machine to call meetings, arouse voters and gain votes because they cannot pay local party agents the pittance they need for their maintenance, open opposition parties tend to concentrate their activities in urban areas. The dominant parties usually have the mass machines which cover the country and reach into rural areas because they have the money.

The impecuniousness of the opposition affects its stability and strength in another way. Paid government office is not available to the members of an opposition party - only support for the governing parties can offer that. This is why members of opposition parties in parliamentary bodies sometimes cross over. Being in opposition is like middle-class morality. As $\mathrm{Mr}$ Doolittle said, it is all very well for those who can afford it. Those who cannot afford it are tempted to make their peace with the ruling party in order to enjoy some of the benefits which association with the ruling party provides. Thus, though open opposition parties are sometimes coerced into amalgamation with the dominant party, the parties and their individual members are also sometimes tempted into amalgamation. The alternatives which face a feeble opposition party are extinction and exclusion and possible persecution on the one side, and a share in income and eminence on the other - with perhaps a little influence as well.

Poverty is not the only reason for the weakness of opposition parties. The oppositional position attracts intellectuals, who are 


\section{GOVERNMENT AND OPPOSITION}

quick to see imperfections because they also have high - sometimes unrealistically high - standards. They also, being urban in residence and attachment, tend to confine their political activities to the urban population. This keeps their parties at a disadvantage vis-à-vis the more populistic majority party which, with its larger number of less well-educated middle and lower rank functionaries, is able to maintain closer connections with the villagers and peasants. Furthermore, intellectuals, especially those in opposition parties, are not very skilful as organizers and administrators. This, too, contributes to the weakness of their parties.

The urban or otherwise local concentration of the support of opposition parties in contrast with the dominant party is to some extent a matter of poverty. It is also a product of the processes of political competition. Pre-independence politics were largely agitational politics, but as the franchise was extended and as agitation became more persistent and widespread before independence, they also required organizational skill. The factions or parties with organizational skill acquired the leading positions in the new governments. The factions or parties of the pre-independence period which could not muster the organizational skill, because their leading personalities tended to conceive of politics only as oppositional agitation and intellectual argument against the ruling power, were left behind as an almost exclusively agitational rump. The truest heirs of the oppositional tradition of pre-independence politics are the opposition parties of the independent new states. Organization and the tradition which prizes organizational skills were not in their heritage.

The 'party of independence' has other advantages over the opposition party in electoral contests. Ignorance, ${ }^{10}$ apathy, a traditional submissiveness to established rulers, as well as loyalty and fear of loss or coercion have given strength to the incumbent parties. Opposition parties, even if they were on a level financially or organizationally with the incumbents, would be at a disadvantage.

There is one further reason for the weakness of opposition parties in most of the new states. That is the rather comprehensive, even if unacknowledged, consensus in most of the societies between the governing party and the opposition parties and groups with respect to modernization through socialistic policies and governmental action.

10 Governments have been changed by general elections only in Ceylon which had the highest literacy rate of all new states at the time of independence. The Congress Party has been defeated in a state election in Kerala which has the highest literacy rate in India. 


\section{OPPOSITION IN ASIA AND AFRICA}

They are also uniformly anti-colonialist. Even though incumbent governments might not be as dynamically socialistic as some of the most vehement opposition ${ }^{11}$ wishes them to be, nor as aggressively anti-colonialist, the ruling party usually does not allow itself to be outdone by the opposition on these themes. Thus even though there are discrepancies between the views of an opposition party and the action of a compromising ruling party, which permits private enterprise and makes arrangements, which some of the opposition think improper, with the Western powers, their language will be much the same. All parties claim to be non-aligned between East and West, and though the governing party inclines towards the Soviet Union or China on the one side or France, Britain and the United States on the other, its rhetoric does not give the opposition party much room to establish its own unique identity. The opposition is deprived of much of its argument, and it suffers further from its inability to formulate its criticism in detailed factual analyses and recommendations. As a result the unsophisticated electorate - which is usually not very much interested in matters of principle in any case - finds it difficult to distinguish between the outlook of the opposition and that of the governing party.

\section{The effectiveness of opposition parties}

Where groups in opposition to the government have been allowed to exist publicly, how well have they done their work ? One of the major tasks of an opposition party is to provide for succession. Among the new states, India and Ceylon have held several general elections with contending parties. In India, the dominant Congress Party has always been successful on a national scale and in practically all the states. Because it has not, however, always had a clear majority in the latter, it has had to form governments with the support of independents and representatives of local parties. When the communists formed a government in Kerala, it could not maintain public order and it was deposed by the central government. Thus India has never yet put opposition parties to the test of forming a successor government. It is only in Ceylon that the opposition party has on a number

\footnotetext{
I Although many of the ruling parties in Asia and Africa compromise with their expressed principles and allow considerable room for private business enterprise, they do not acknowledge this at the level of principle. In principle, they nearly all say that they are socialist. So do almost all oppositional parties. There are very few parties which explicitly designate themselves as parties of free enterprise.
}

189 


\section{GOVERNMENT AND OPPOSITION}

of occasions succeeded in winning over the incumbent party. ${ }^{12}$ It is difficult to assess the accomplishments of each of the successive governments in Ceylon or to decide whether the prospect of forming a government after a general election has made opposition parties more responsible and more competent than they otherwise might have been when they did accede to power.

The Nigerian general election of 1965 was a fiasco, perhaps because of the hopelessness of unseating the dominant party electorally. In Lebanon, the very prospect of a general election has several times precipitated a succession crisis and once a civil war, because the incumbent president did not wish to renounce office although constitutionally required to do so. In all the other new states, succession, where it has taken place, has been the result of a coup d'état by the military, of assassination (once in Ceylon by monks and civilians, without affecting the dominance of the ruling party), or of a putsch (Congo-Brazzaville and many other countries).

In most new states the dominant party has remained dominant. The opposition has nearly always been a poor competitor for the succession. This failure to perform one major function of an opposition is not attributable to itself alone. Incumbent elites in many of the new states have taken the measures available to them as controllers of the apparatus of the state to prevent their replacement. But even where they permit a constitutional attempt at replacement the opposition has seldom been successful.

The ineffectiveness of opposition parties as contenders for the succession is in turn the factor which determines the ineffectiveness of the opposition as a critic and corrector of the policies of those governments which have allowed them to exist. Where the illiteracy and political impermeability of the populace render ineffective the efforts of a poorly organized opposition party, the governing party has nothing to fear from it. There is no need for it to modify its policies to avert or to satisfy criticism. It need have no fear that the criticisms of the opposition party will instruct the electorate about its shortcomings and turn them against it. The ruling party is usually aware that the opposition party cannot reach the mass of the population and that the activists in their own party are bound to them by ties of pecuniary advantage and belief.

What would an opposition party have to do in order to influence

12 The numerous reconstitutions of government in Pakistan before 1958 were the outcome of arrangements among politicians and not of a succession realized through a nation-wide election. 


\section{OPPOSITION IN ASIA AND AFRICA}

the leaders of the governing party? It would have to be able to address itself persuasively to the bearers of political opinion, to which the governing party is sensitive. ${ }^{13}$ In many of the new states, however, the most effective political opinion is likely to be the opinion of activists within the ruling party, the leaders of youth organizations, and locally and territorially based notables. The activists are bound to the ruling party by belief and by the prospect of a continuing flow of material benefits. Youth organizations tend to be auxiliary organizations of the dominant party, which alone has the resources to pay for them. The leaders of youth organizations are often paid officials of the dominant party. Locally or territorially based notables, unless they are already the pillars of a primarily ethnic or communal opposition party, are difficult to reach because to do so requires more financial resources and manpower than most of the opposition parties dispose of. Moreover, concerned as they are with local interests and attached as they are to their own local community, local notables are not likely to take the risk of arousing the wrath of the ruling party, which has almost everywhere shown its ability to discipline recalcitrant traditional elites. ${ }^{14}$ The latter generally find it convenient and profitable to present a show of conformity with the wishes of the ruling party.

Are there any other more independent and weighty bearers of public opinion whose opinion and whose organized power the government fears? Professional persons - university and secondary school teachers, students, engineers, accountants, journalists, writers, scientists, businessmen, leaders of voluntary associations, and trades union leaders are the possible publics for the opposition party's criticisms of government. But what is the likelihood that an opposition party can win these groups to its support and thereby make the governing party more responsive to its criticisms to the extent at least of modifying certain criticized policies, even if it does not accept the positive demands of the opposition party for particular policies?

It is extremely difficult for trades unions to become independent in new states. The ruling parties correctly see that the only potentially

13 One of the most substantial achievements of an opposition party in bringing a government to change its policy was the decision of the Nigerian government to revise the defence pact which it had made with the United Kingdom. This victory for a critical opposition party was greatly facilitated by the vigour of the free Nigerian press.

14 It is perhaps thanks to the relatively firm constitutional outlook which prevails in India that traditional territorial notables there have been permitted to support an opposition party. Witness the role of the quondam princely families in the Swatantra Party in Bihar and Rajasthan. 


\section{GOVERNMENT AND OPPOSITION}

strong civilian organizations which can challenge their power are the trades unions, however poor and small they may be compared with the trades unions of highly industrialized countries. Political prudence and doctrine both dictate a policy of strong governmental control over the leadership of the trades unions. In most cases, the trades unions were created for political purposes by the 'party of independence'; many of the leaders of the unions are still closely linked to the elite of the dominant party. Furthermore, the latter usually take some pains to control the new generation of trades unions leaders. Trades union leaders who wish to be effective on behalf of their rank and file and who therefore wish to be a little free of the control of the dominant party will therefore be circumspect about the open defiance of the dominant party elite implicit in association with an opposition party.

India and Ceylon present instances where trades union leaders are allowed this luxury, but again, this is made possible because the constitutional tradition of the dominant party permits it. It does not happen in states where the dominant party is hypersensitive to danger and unrestrained by constitutional tradition. ${ }^{15}$ It certainly does not happen in one-party or quasi-one-party regimes.

Businessmen will not give financial support to opposition parties, nor will they otherwise show sympathy with them. Where the major large-scale entrepreneurs are nationals of the former ruling power or members of an ethnic minority, they will not be inclined to do anything to arouse the displeasure of the ruling party. Being businessmen and ethnically alien are sufficient causes in their own right to make them suspect to the ruling party. Only where there are indigenous businessmen (or businesswomen) who have a stake in the country and feel free to think of their own advantage - and when there are enough of them to give the additional weight of the consciousness of numbers to their self-esteem - will they form a potential support for opposition parties. On the whole, however, they prefer to work through the dominant party for reasons given earlier.

Finally, the professional classes, the engineers, the teachers, the scientists, and the journalists and literary men. In most countries except India, Pakistan and Nigeria, they are few in number and unorganized. They are, moreover, disproportionately in the employ of government and they are therefore relatively unresponsive, in practice, to an

15 The success of the Nigerian strike action and the failure of the Ghanaian unions in a similar action merit further consideration. The former was the most unique achievement of a trades union movement in an Afro-Asian state; the conditions for its success are obscurc to me. 


\section{OPPOSITION IN ASIA AND AFRICA}

opposition party, however sympathetic they may be in sentiment. Their scanty numbers make for weak self-confidence. They have little or no autonomous professional culture; their institutional structure is too weak and too dependent on the government for their selfconsciousness as intellectuals to establish them as an 'estate of the realm'.

University teachers form perhaps the only section of the professional classes which possesses some of the qualifications for constituting a 'critical opposition', though not an opposition party. Some of them have expert knowledge in the spheres in which governmental policies operate. Their university institutions enjoy in many instances legal autonomy. They themselves are members of a sustaining international intellectual community. They are, in principle, experienced in detached and disciplined judgement. All these characteristics should contribute to the exercise of matter-of-fact and independent opinion. Many of them, more over, continue the oppositional traditions of their forerunners in the independence movement. Nonetheless these do not add up to effective support for open opposition parties.

In India, Pakistan, and Indonesia, where they are indigenous and numerous, they are neither esteemed by others nor are they sufficiently self-esteeming. ${ }^{16}$ Very few of them are well informed about current affairs, nor do they have a tradition of expressing themselves forcefully and in a well documented way in print. They do not have organs through which they can express themselves, either. In Ceylon they are too few in number, and the same restraints obtain there too. In the Middle East the situation is not too different from South Asia. They are discontented with their governments but they are afraid to express themselves openly. In Black Africa, on the senior level they are still largely expatriates and therefore hors de concours. At the junior level, where indigenous persons are more common, they are too young and too inexperienced to respond to and to contribute to the life of an opposition party. Thus, oppositional sentiments of the university intellectuals do not redound to the advantage of an opposition party. University students in the new states are often oppositional in sentiment and very active too but they lack organization and discipline. Moderate oppositional parties find little response among them. Governments are wary of them but do not take them seriously.

Thus the points of support in public opinion for opposition

10 Economists in India and Pakistan are beginning to acquire the status which is a necessary condition for influence. 


\section{GOVERNMENT AND OPPOSITION}

criticism, outside the legislative body and outside the political parties, are really quantitatively too slight, too low in prestige, and too unfocused to enable oppositional parties to make their criticisms carry weight with the governing party.

\section{Closed opposition: opposition outside opposition parties and the institutions of public liberty}

The decision of a ruling party to paralyse or to extinguish its rival parties simply removes opposition, except in severe crisis, from where it can be seen. Oppositional activities and assertions receive little or no publicity except post facto: after they have been defeated and condemned or after they have been victorious. (In the latter case, the previously secret opposition gives evidence of its previous existence by its displacement of the hitherto incumbent regime.)

The existence of oppositional activities in regimes which have committed themselves to their abolition can, of course, not always be hidden or suppressed. In the Sudan, the final abdication of the regime of General Abboud was precipitated by the public activities of students in the last days of the regime and the final appearance in public of the secret opposition of the civilian politicians. The repeated upheavals in Iraq and Syria have occurred in regimes which had declared that there was no need for a diversity of parties because the ruling party spoke for all the people except for remnants of the ancien régime which had to be crushed. The conspiracies against the government in the Ivory Coast, in Dahomey, and in Togoland were carried out by legally non-existent groups. All these indicate that there is opposition in the monolithic new states but the opposition which is thus manifested is concerned to perform only one function of opposition - namely to succeed the incumbent elite. The absence of institutionalized and open opposition parties only makes it more probable that the problem of succession will be attended by subversive action.

Closed oppositions, like open oppositions, wish to accede to power but they are also concerned with policy. Indeed, in certain respects, their concern with policy is sometimes more genuine than that of open opposition parties, because they are not contending for electoral support.

The new states are full of problems of policy which generate conflicting interests and give rise to opposition. There is much mute opposition. No adequate explanation of the failure of economic policies is possible which does not refer to the refusal to collaborate of a 


\section{OPPOSITION IN ASIA AND AFRICA}

hostile peasantry. ${ }^{17}$ Failure can of course be attributed to poor planning, to the setting of unrealistic targets, which assume capital to be available when it is not. But some of the poor planning consists in predictions and efforts to control peasant behaviour which turn out to be incorrect. To describe the failure simply as a cognitive shortcoming on the part of the planners is to overlook the obstinate non-compliance of the peasantry. Apathy, uninformedness, and sheer indifference are not the same as opposition but there are also many peasant actions which cannot be accounted for solely by unawareness or inefficient communication. The fact that they do not 'receive the messages' of the planners, politicians and civil servants is not a result of a mechanical gap. The peasants do not listen. They 'play doggo' because they distrust those in authority and do not wish them well. If the governing party will not do what they wish, they for their part will not do what that party wants them to do.

The peasantry then constitutes the foremost, most massive, most powerful opposition in all new states - in those without opposition parties as well as in those with opposition parties. Parties have little to do with it. The peasants might vote for the ruling party because it has some semblance of a rural organization and because they hope to win some particular favours from its politicians in return for their votes. But they will do little to comply. with the exhortations and targets of the ruling elite. They are not interested in programmes but in particular services which the politicians can perform for them. They give their votes in return for these favours, but they do not give their collaboration to the government's schemes for rural modernization. Their non-compliance is an opposition of withdrawal and noncooperation. It does not argue for a policy, since it has no one with whom to argue or who will argue on its behalf.

The trade unionists are a little better off: they have an organization and they have leaders who must please them and who move in the circles of the mighty. Their opposition is most likely, therefore, to be a closed, positive, policy-oriented opposition, frequently a radical intra-party opposition, which often overlaps with the opposition of the educated youth.

Incumbency of positions of authority has a 'conservative' effect. It is difficult to get much done in a new state. The obdurate immobility of the peasantry, the shortages of highly trained manpower, the shortages of capital, the cumbersomeness of the rapidly expanded

17 Disobedience to the enactments of governmental authority arising from indifference, and deliberate breaking of the law are at the margin of opposition. 


\section{GOVERNMENT AND OPPOSITION}

machinery of government, the greater conservatism (or realism) of civil servants as compared with politicians, all make it difficult for politicians aspiring to rapid modernization to accomplish as much as the myth of modernity seems to call for. Incumbency also makes, at least in a minimal measure, for a sense of responsibility. It teaches the lesson that not everything is possible simultaneously, that the public peace must be kept because disorder might result in expulsion from power. As a result, however 'progressive' a government may be in doctrine it cannot please those whose aspirations are unqualified by the intractable reality of trying to govern a poor and unconsensual society. Those who are left dissatisfied constitute a radical closed opposition, composed as Professor Arthur Lewis has recently said of Africa, of unemployed primary school graduates looking for unavailable clerical jobs, primary school teachers, small traders who cannot compete with the Lebanese, men who resent chiefly authority, unsuccessful claimants to chieftaincy.

This radical closed opposition is tolerated because it cannot be suppressed without great difficulty, and, more important, because it enjoys the protection of certain members of the innermost elite who regard it as a valuable adjunct for their own potential opposition to those who are in the most central positions or who might challenge or threaten them. It is a useful instrument for the convocation of demonstrations, for producing a display of violence when that is thought necessary to intimidate recalcitrants. The radical wing has its own organs of expression. It sometimes is allowed a distinctive organization; this is most likely when it is largely congruous with the youth wing of the party. It sometimes has its own publications, subsidized by the ruling party. This relationship of patron-beneficiary testifies to the fact that the radical wing is often very much an instrument of the closed opposition of a senior politician in the inner circle, to be used for putting pressure on rivals or intimidating potential or residual opposition outside the party. This patron-beneficiary relationship also appears to indicate that the radical wing is not an autonomous oppositional force. It has no power of its own. If it had no friends at the centre of authority, it would be courting suppression. (This does not mean that it will always be so; it might conceivably break away from its usually more conservative patrons and controllers and become an autonomous group in its own right.) Sometimes, concessions often more symbolic than substantial, are made to it.

There are other possible loci and bearers of closed opposition in I 96 


\section{OPPOSITION IN ASIA AND AFRICA}

the new states. Traditional leaders - chiefs, sultans, monks, the ulema, civil servants, journalists, intellectual leaders. Traditional leaders have been swept aside with remarkable ease in most countries. Not that they have lost the affections or deference of their people. Despite their subservience to the colonial powers, their people did not desert them. Their 'collaboration' injured them mainly with the intellectuals, who would have been against them in any case. The small scale of their sovereignties, the shambling administrative machinery through which they exercised their authority, their military insignificance, have all contributed to their defeat at the hands of the modern political elites. They are an opposition group, but a powerless and silent one. They are not acceptable enough to the ruling party to become an internal closed opposition; they are not permitted to organize politically, or if they are organized, their organizations are too flimsy and too narrow for them to be effective. They have little that they can withhold except their approval. Where they have no monastic organization to sustain them, as do the monks in Ceylon and South East Asia and the quasi-ecclesiastical organizations of the ulema, they have nothing to sustain their resistive power. Furthermore, in most cases, in consequence of land reform or because of the traditional system of land tenure, they have no financial resources to enable them to exercise the powers which patronage provides. Even in Lebanon, the power of the great families of $z a^{\prime} i m$ over their traditional clients is declining. The upshot of all this is that the traditional landlord and chiefly elites can withhold their support and therewith the legitimacy which their prestige still carries with it, but they can exercise little positive influence on the policies of the modern political elites organized in the ruling party.

As far as intellectuals are concerned, the weaknesses to which we referred in discussing the obstacles to their provision of resonance for opposition parties operate here, too. The educated classes outside government are too small, too lacking in solidarity, too lacking in prestige and self-confidence to impose their views on the incumbent political elites. Individual intellectuals do have some influence - but largely as economists and as economic advisers in government service. No intellectual organ in any new state, except perhaps the Economic Weekly in India, has any influence on what officials in governments think - and there, too, it is through its influence on civil servants and economic advisers in ministries and in the Planning Commission that it has some positive oppositional influence. The intellectual press, both professional and publicistic, is weak 
economically, too ill-informed, and too lacking in prestige to establish the ascendancy required to impress the politicians of the ruling party.

Thus we see that in one-party and quasi-one-party states, positive policy-oriented closed opposition is the prerogative of politicians and civil servants, and marginally and intermittently of military men and trades union leaders. In the two former instances, opposition is real and sometimes effective, but it is closed. When trades union leaders express oppositional attitudes, it is most usually done behind closed doors. It is only when they very occasionally break out of the public façade of unanimity by instigating strikes that their opposition comes before a wider audience. When in Congo-Brazzaville and in Guinée and Ghana, public trades union opposition broke the permitted boundaries, the result was subversion in one case and suppression in the others. The opposition of the military also has only those two alternatives. The military being better organized and stronger than the trades unions is more often able to achieve the former and avoid the latter alternative. Except for civil servants, whose opposition is institutionalized as closed opposition, the other carriers of uninstitutionalized, closed opposition are impelled towards secrecy as well.

In India, with its freedom of economic and social inquiry and journalistic reporting and editorial analysis, the cleavages between opposition and ruling party can be seen fairly clearly. In Israel, the energy of the parties to the coalition makes the lack of unanimity quite obvious to the public eye. It is approximately the same in Nigeria and Sierra Leone. Not only the acts of opposition are visible, but the promulgation of the grounds of opposition and the preparation for its exercise are also open.

In contrast with these countries, in one-party states, the uninstitutionalized situation of closed opposition makes also for secrecy in its promulgation of policy and its preparation of action. It becomes more conspiratorial in character and therefore more susceptible to accusations of subversive intention. It is bound to lead a more tenuous, more delicately poised existence simply because it is closed. The public is excluded from awareness of closed opposition and contributes and gains nothing from its operation. It is the passive recipient of such improvements as might be brought about by closed opposition. The wider society is not even a spectator of closed opposition; the delicate filaments which link leaders and constituents in situations of open opposition are almost entirely lacking in systems of closed opposition.

It is contended that the interests and desires of the populace are 198 


\section{OPPOSITION IN ASIA AND AFRICA}

adequately cared for under these conditions, particularly inasmuch as there are elections in which a choice between alternative candidates is permitted and parliamentary bodies whose approval is required for the actions of government which are to take legislative form. It is necessary to consider the extent to which closed opposition allows for the representation of sectional interests and desires.

The functions of opposition and their performance in new states with regimes of closed opposition

All states of any degree of complexity require for their orderly survival: (I) the disciplining of conflict through the institutionalized representation of conflicting 'interests' and their containment within the bounds of public order; (2) the expression and therewith communication to the government of interests and desires which might be neglected or otherwise disregarded; (3) the provision for an orderly succession; (4) the improvement of the performance of the government by criticism of mistakes, omissions, and injustices of past performance, thereby enabling the government to avoid such actions as would lay them open to especially damaging criticism and to disorderly subversion. States which allege that they are in some sense democratic or the elite of which is populistic are further committed in principle to (5) the instruction and enlightenment of the public, the improvement of its discipline in expressing its demands, the improvement of its qualifications for approving or disapproving of the actions of its rulers and for deciding whether to give or to withhold their support.

These are tasks which are more or less well performed in advanced countries with well-developed party systems. For reasons already given, they do not appear to be well performed in the new states, although some of them are performed better than others. The level of performance also varies from state to state within the world of multi-party systems. Are they performed better in one-party states in Asia and Africa; are open opposition parties superfluous because the tasks are adequately faced and resolved in a one-party state ?

In a society in which the sense of 'interestedness' (or interestaffectedness) is not acute because of ignorance, apathy or lack of organization, the conflicts, insofar as large sections of the society (i.e., the 'masses') are concerned, need not become very severe. Nonetheless, there will certainly be some who believe in their interests and will wish them to be realized, or at least represented and expressed. If their interests are not those being promoted by the ruling 


\section{GOVERNMENT AND OPPOSITION}

party, the absence of a publicly organized opposition will reduce the likelihood that those persons or sectors of the society will be able to make their desires known to the ruling party through organs which they regard as in some sense extensions of themselves.

One-party states claim that there are no real interests other than the interest of the whole society which is represented by and cared for by 'the party'. Sectional interests are from this standpoint illegitimate and disintegrative. This metaphysical belief is not often taken very seriously in practice. Repressive measures on the one hand, and claims, on the other, that the 'party's' internal system of upward communication enables it to understand and respond to the 'masses' better than any other system show that the doctrine of unity is not regarded as entirely adequate. But even if the argument is made that 'the party' can in fact perceive the desires of the mass of the population through its mass organization, with the corollary that the mass organization permits desires to be transmitted upwards into the party hierarchy to the point of decision, what is the assurance that they will be taken into account by the leadership ? It is to the 'interest' of a public opposition party or a public oppositional non-party organ to speak on behalf of these otherwise neglected interests. It is not necessarily to the interest of a parti unique to do so.

In fact, what seems to happen in regimes without open opposition is that even if some desires are correctly perceived and transmitted upward to the point of decision, they are often disregarded if no one there believes in their validity or thinks that to disregard them will endanger the security of the regime - and the latter might as easily result in repression as in gratification.

Conflicting interests - but not necessarily neglected interests - and ideals might become incorporated into the structure of a one-party regime as factions. Much of the activity of a faction once it gets consolidated is the preparation for its assumption of the dominant position in the party. Since, however, it is not admitted by others or by itself (publicly) to have that intention, it is bound to be regarded as conspiratorial. Factions can certainly perform some of the functions of opposition, but because they are not acknowledged as legitimate by those who are members of other factions, they are in danger of being regarded as treasonable, and are therefore liable to suppression. But even if they are not, they aggravate conflict and they arouse great tensions about succession. Furthermore, even where a factional system is well established, by virtue of its closed character it neither instructs the populace nor does it receive its sentiments. 


\section{OPPOSITION IN ASIA AND AFRICA}

The underlying conception of a one-party regime is that it represents a comprehensive consensus which embraces everyone in the society, or all except a few enemies of society, motivated by class, tribal, or simply self-interest. The proponents of one-party regimes assert that within the party there is full, frank and fearless criticism and discussion of alternatives. It is questionable whether this is so, even where the leader of the party would seem to wish it to be so. For one thing, it is difficult for critics to obtain the information necessary for criticism. Then, too, it is often unsafe for critics to criticize because they are in danger of being called fomenters of factionalism.

The emergence of new factions is more of a shock to the dominant group of a single-party than is an open opposition party to a ruling party within a two- or multi-party system in which, however, repugnant, the divergences are at least predicted and accepted. Because factions are not institutionalized and therefore verge on the treasonable, they intensify conflicts over the succession and increase the acerbity of the response which the ruling group in a dominant party makes to its closed opposition. This, in turn, makes it more difficult for a faction as a form of closed opposition to act as an effective critic of the policies of the dominant group within the party. The relations of dominant group and faction tend more towards the Freund/Feind relationship than to the consensual one. Nonetheless, despite these liabilities, it is quite certain that factions will exist in a single party, even though strong-minded, powerful and artful leaders like Mr Bourguiba or President Nasser can keep them in check and prevent them from influencing their policies.

Insofar as factions confine themselves strictly to the representation of interests and to attempts to influence the performance and policy of the dominant group in the party, either from an 'interested' or a 'disinterested' standpoint, they stand more chance of being tolerated by the dominant group. They probably also stand more chance of being tolerated if they are intermittent in their operations, being formed from shifting membership and with changing boundaries, as occasions arise. Yet there is a tendency for factions to become stabilized and for the same group of persons to take corresponding positions on a variety of issues. This can scarcely be avoided, because the major positions on any particular issue have logically, morally, or traditionally corresponding positions on other, not directly related, issues. Furthermore, the actions of a group of men on a particular issue in which they took similar stands at any one moment, alienates others who nurture their grudge long after its initial occasion. This, 


\section{GOVERNMENT AND OPPOSITION}

too, leads to a stabilization of faction, and although it might make the faction more effective for a time, it also heightens antagonism towards it and renders more likely its suppression or an effort at its paralysis. Persistence in criticism from a faction of stable composition, on behalf of particular interests or ideal conceptions as to how the society should be ordered, heightens the danger for the critics of expulsion from the party, or demotion.

The fundamental fact of the closed character of opposition means that the focusing and concerting of interests and desires outside the ruling party are inhibited. From the point of view of the security of the ruling party's retention of its position, this is an advantage. From the point of view of social justice and the adjudication and compromise of conflicting interests, it is not an advantage.

The closed character of opposition excludes the populace, and the educated classes which are not in the elite of the ruling party or of the organizations which the ruling party permits, from any intelligent participation in and contribution to the formulation of the general lines of policy which will affect them. If closed opposition could be combined with public liberties, especially in academic social sciences, journalistic and editorial activities, the deficiencies of closed criticism would perhaps be compensated for. Unfortunately, this combination seldom occurs. Nor is it likely to do so.

The improvement of governmental action through informed criticism and the enlightenment of public opinion by such criticism within and outside governmental institutions are particularly difficult to achieve in new states, regardless of whether they are one-party or multi-party regimes. The difficulty is in the first instance a result of a deficiency in the supply of reliable information. Practically all new states suffer from an inadequate press. This is not solely a function of limits on the freedom of reporting and publication - although the absence of that freedom is a severe handicap - but rather of the resources of the press and the quality of journalistic personnel. These are in turn partly determined by the poverty and illiteracy of the mass of the population, which deprives journalists of financial support and an exacting public. The independent gathering of information by experienced reporters occurs relatively rarely in the new states, partly because there are too few experienced reporters and because there is insufficient appreciation of the value of that type of journalistic activity. There is neither a tradition which can sustain it, nor do the leaders of one-party states desire it. The privately-owned press in the new states, handicapped by the poverty of its potential audience, 


\section{OPPOSITION IN ASIA AND AFRICA}

which deprives it of revenue from advertising - there are also relatively few firms rich enough or expansive enough to advertise - is further handicapped by the denunciatory and hortatory traditions of a journalism formed in the days of the struggle for independence.

As a result, politicians do not have much factual basis for their criticism of governmental actions and interests. This applies equally to public and to closed opposition. The situation is aggravated in regimes of closed opposition - one-party states - by the legal and political restraints on the freedom of journalists to discover, disclose and comment. Nor is this shortcoming made up for by other organs of opinion, such as a periodical press, less concerned with the account of day-to-day events, and a professional social and economic research press, more concerned with detailed documentation and long-term evaluation. Here, too, it is not solely a matter of the repression of intellectual freedom. Even in countries like Uganda, Kenya, Sierra Leone, or Pakistan, or wherever intellectual freedom is relatively unrestricted, this informative and evaluative function - which is indispensable to effective opposition - is not being performed because not enough information is generated by the personnel of the periodical press or the research institutes. They are too few in number to create a dense mass of information in the light of which government actions can be described, interpreted and assessed.

Where there is no independent gathering and criticism of facts, the government's own reporting function is unconstrained by the danger of authoritative contradiction. The ruling party can claim successes which no one can contradict, either because he does not know what the real facts are, or because he would get into trouble if he were to make known such facts as he does know.

Now it is quite conceivable that even though public criticism and opposition are not tolerated, the government might establish within its own narrow confines an independent investigative, reporting and information service which would enable at least the leading members of the governing party to know what the government is achieving and where it has fallen short. In a sense, there is such a service. The government intelligence service, the party apparatus at the 'grass roots' level ${ }^{18}$ and the experience of politicians as they travel about

18 All the mass partis uniques claim to have this institution and put it forward as a justification for not permitting expression of opinion through opposition parties. Tanzania, Mali and Guinée seem to make an ef ort to make the system work, but in other countries local agents regard it as their job simply to get out the votes and to take note of critical attitudes for security purposes, but they co not pay much attention to the upward flow of opinion from the lower strata of society. 


\section{GOVERNMENT AND OPPOSITION}

and enquire, as well as the inspectorates of the various ministries, provide such a reporting service. The government does not act, therefore, in utter darkness.

But can critics, even within the closed circle of the ruling party, get at this information? Within the leadership of the party, they probably can, particularly if they are members of the dominant faction or have close connections with it. Such information is not available to the public outside the party; and given the difficulty of extracting it from those who possess it, it is not so likely to be available to the minority factions. Moreover, without the spur of possible criticism from outside, there is no incentive on the part of those who are responsible for the implementation of policies to report facts which will disclose the deficiencies of their performance.

In consequence, mistaken policies are often persisted in rather than corrected. Of course, even if information were available, it might not correct policies which are wrong, because doctrinaire prejudices, wrong economic theories, and vanity might blind the leadership of the ruling party to the more correct representations of their civil servants and advisers, and their intra-party critics. But correct factual information, especially publicly available information, at least makes rulers more circumspect about policies which fly in the face of accredited facts. In the course of time, it might even bring about a change in policy.

This informative-evaluative-corrective function is one of the most important functions of any opposition. It is a function which not all public and institutionalized opposition parties perform. It cannot be performed when the body of facts simply does not exist, and when the possibility of the assembly, presentation, and interpretation of those facts is prevented. It cannot be performed where there is no freedom of inquiry, publication, or public discussion. 